\title{
Physical development of hockey players aged 13-16 years
}

\author{
Surina-Marysheva E.F. ${ }^{1 \mathrm{ABCD}}$, Erlikh V.V. ${ }^{1 \mathrm{ADE}}$, Korableva Y.B. ${ }^{1 \mathrm{BCD}}$, Kantyukov S.A. ${ }^{2 \mathrm{ACD}}$, Ermolaeva E.N. ${ }^{3 \mathrm{ACD}}$ \\ ${ }^{1}$ Institute of Sport, Tourism and Service; South Ural State University (National Research University), Russia \\ ${ }^{2}$ Department of Biological Chemistry, South Ural State Medical University, Russia \\ ${ }^{3}$ Department of Pathological Physiology, South Ural State University (National Research University), Russia
}

Authors' Contribution: A - Study design; B - Data collection; C - Statistical analysis; D - Manuscript Preparation; E - Funds Collection.

\begin{abstract}
Purpose: Identify the age features of hockey players aged 13-16 years old physical development.

Material: $\quad$ Elite hockey players $(n=83$, age - 13-16 years) were surveyed. Standard anthropometric methods for measuring length and body weight were used. The body mass index (BMI) was calculated.

Results: $\quad$ The average value of the body length of hockey players did not differ from peers, who do not engage in sports. The cental distribution of the absolute values of the indicator relative to nomograms has been shifted to the right. Most hockey players had average body lengths. The excess of the average body weight of hockey players was recorded in comparison with the average population values. The cental distribution of absolute values was characterized by a significant shift to the right (range 3\% -90\% percentile). Most hockey players had a body weight "above average" (55-66\%). The group of athletes with body weight and BMI "below average" was $6 \%$ (age from 13 to 15 years).

Conclusions: The physical development of elite hockey players is characterized by an average body length with a tendency to shift to values "above average". The proportion of hockey players with mean body lengths below the midpopulation is very small. Elite hockey players are characterized by large body weight and BMI compared to peers who do not engage in sports. As the age increases from the morphological criteria, the body weight and BMI have the greatest value for the hockey player's success in sports selection.

Keywords: athletes, ice hockey, pubertal period of development, body length, body weight, body mass index.
\end{abstract}

\section{Introduction}

The anthropometric profile of athletes is determined by the two most important interrelated factors: sport selection and the impact of specific physical (muscle) loads. The physical development of most adolescents is harmonious with the mean length and body weight relative to the population. With the increase in sports experience, the proportion of athletes with body length and body weight "above average" and "high" is greater [1-3]. In this case, the appearance of secondary sexual characteristics in athletes occurs later in time. The main reason is the delay in the onset of the pubertal period of development $[4,5]$. It is known that anthropometric parameters (length and body weight) have a high degree of genetic determinacy $[6,7]$. Therefore, the nature and intensity of physical exertion can have a positive and negative impact on the pace of physical development [9-11]. Anthropometric parameters are often used as indicators of the success of athletes $[12,13]$.

Adult highly skilled hockey players are characterized by a relatively large body weight $(91.4-94.5 \mathrm{~kg})$ and body length above the average (185.3-186.5 cm) [14-16]. There is a correlation between the success of international teams and the body mass indicator and body mass index (BMI) [17]. A similar relationship is revealed in relation to the rating of hockey leagues within individual countries [18]. The power character of the game is typical even for children and youth hockey with a puck. This causes close attention to the anthropometric profile of young hockey players. In various countries, power collisions have been

(c) Surina-Marysheva E.F., Erlikh V.V., Korableva Y.B.,

Kantyukov S.A., Ermolaeva E.N., 2018

doi:10.15561/18189172.2018.0207 permitted since the age of $10-12$ years. This leads to a significant increase in the risk of injury to hockey players of childhood and adolescence [19-21]. Hockey agents and scouts of hockey teams pay much attention to the analysis of the indicators of game statistics and physical development parameters of prospective players [22]. In the future, successful athletes participate in competitions in hockey leagues of North America.

The pubertal period is a critical period of development. This is reflected in the appearance of relative instability in the parameters of activity of all functional systems of the body. There is an active neurohormonal change, which leads to significant alterations in the physical development of children. Absence or insufficient consideration of the age characteristics of a young athlete organism can lead to a slowing-down in physical development. During this period, the risk of injury significantly increases. This is especially noticeable in hockey with a puck $[13,17]$.

For non-sporting children, there are age-sex regional nomograms that are used in pediatrics [23, 24]. In the scientific literature, data on the anthropometric profiles of hockey players of the pubertal period of development are few and isolated. However, knowledge of the features and regularities of the parameters of total body size and physique in the age aspect are necessary for sports athletes.

Hypothesis - there are specific features in the parameters of hockey players' physical development of the puberty period of development, depending on age.

Material and methods.

Participants. Male hockey players $(\mathrm{n}=83$, age 13- 
16 years) were examined. Game role - forward and fullback. In the distribution of groups were taken into account the features of physical development: the beginning of the pubertal period is characterized by great variability in the parameters of physical development [19]. The distribution for groups was conducted in steps of one year: 13 years old hockey players (mean age $13.31 \pm 0.48$ years, $n=$ 16); 14 years old hockey players (age $14.22 \pm 0.42$ years, $\mathrm{n}=26$ ); 15 years old hockey players (age $15.22 \pm 0.43$ years, $n=18$ ); 16 years old hockey players (age 16.24 \pm 0.44 years, $n=23$ ). As comparison groups, the data of children and adolescents of the South Ural region of Russia for 2002-2014 were used. [25, 26]. The study followed ethical measures to conduct scientific research in accordance with the Helsinki Declaration.

Organization of the study. The physical development of hockey players was studied on the basis of the specialized children's and youth school of the Olympic reserve (SCYSOR) "Tractor" (Chelyabinsk, Russia). This school is one of the best hockey schools in Russia. A prospective cross-sectional study was conducted. The terms of the study corresponded to the beginning of the preparatory period. Anthropometric studies were conducted according to the standard method using standard instruments [9, 27]. Measurements of body length and body weight were carried out. BMI is also determined. The research conditions were standardized: morning time; on an empty stomach. To assess the characteristics of physical development of hockey players were used centile tables [23]. According to the medical-physical examination, hockey players are healthy children. Therefore, the study adopted the following distribution of anthropometric indicators relative to nomograms: interval $25-75 \%$ percentile - "medium", $25 \%$ percentile and less - "below average"; $75 \%$ percentile and above - "above average".

Statistical analysis. For the statistical processing of the results of the study it was used a package of statistical programs "Statistica.10.0": descriptive statistics methods, parametric methods for determining the reliability of the differences between unrelated samples by the Student's criterion.

\section{Results.}

The average value of hockey players' length and body weight was the following: at the age of 13 years - 159.9 $\pm 8.3 \mathrm{~cm}, 175.3 \pm 6.6 \mathrm{~cm}$; at the age of 15 years $-51.9 \pm$
$8.0 \mathrm{~kg}, 64.4 \pm 8.0 \mathrm{~kg}$ (Table 1). These data did not differ statistically reliably from the values of anthropometric indicators of children not engaged in sports [15] ( $>>0.05)$. According to the length of the body, hockey players aged 14 and 16 did not differ from peers who did not engage in sports [15] ( $>0.05)$. The weight of the body of hockey players was more $(\mathrm{p}<0,05)$. BMI of hockey players had more indicators of children not involved in sports $[15,20]$ ( $\mathrm{p}<0.05$ in all cases).

The cental distribution of the absolute values of the hockey players' body length (13-16 years) relative to nomograms was shifted to the right (Table 2). The least pronounced shift was recorded in the centile interval of "very high" body length $(97 \%$ percentile, from 14 years to 16 years). The centrally distributed absolute body weight of hockey players (13-16 years) relative to nomograms was characterized by uneven shifts to the right, depending on ranges and age (Table 2). The most significant shift to the right was recorded in the range of 3\% -90\% percentile in all age groups. The body weight of hockey players (at 13 and 15 years old) with very high values of the indicator (97\% percentile) did not differ from peers who do not engage in sports. In all the centile intervals, the indicators of hockey players' BMI (14 and 16 years) relative to nomograms [23] was revealed a shift to the right. In hockey players of 13 years old, the shift of the centrally distributed BMI to the right is determined only for the range of $3 \%-75 \%$ percentile. The hockey players of 15 years old: the shift to the right is fixed only in the range of $3 \%-50 \%$ percentile; in the intervals of $90 \%$ and $97 \%$ percentile, the absolute values of BMI are even smaller than in nomograms.

Among the age group of 13 years, $50 \%$ of hockey players had a mean value of body length for the population relative to nomograms: $38 \%$ - "above average" and $12 \%$ - "below average" (Figure 1). In the age group from 14 to 16 years, the value of body length "average" and "above average" are saved. The relative number of hockey players with a body length "below average" during this period was stable (6\%).

A group of hockey players with a body weight "above average" was $55-66 \%$ of the total sample (Figure 2). A group of hockey players with a body weight of "below average" was $6 \%$. This group was allocated only up to 15 years of age.

Table 1. Anthropometric indicators of hockey players from 13 years to 16 years

\begin{tabular}{lllll}
\hline Group & $\mathbf{n}$ & $\begin{array}{l}\text { Body length }(\mathbf{c m}) \\
\mathbf{M} \pm \mathbf{m} ; \boldsymbol{\sigma}\end{array}$ & $\begin{array}{l}\text { Body mass }(\mathrm{kg}) \\
\mathbf{M} \pm \mathbf{m} ; \boldsymbol{\sigma}\end{array}$ & $\begin{array}{l}\mathbf{B M I}\left(\mathbf{k g} / \mathbf{m}^{2}\right) \\
\mathbf{M} \pm \mathbf{m} ; \boldsymbol{\sigma}\end{array}$ \\
\hline $\begin{array}{l}13 \text { years } \\
\text { old }\end{array}$ & 16 & $159,9 \pm 2,1 ; 8,3$ & $51,9 \pm 2,0 ; 8,0$ & $20,2 \pm 0,5 ; 2,1$ \\
$\begin{array}{l}14 \text { years } \\
\text { old }\end{array}$ & 26 & $168,9 \pm 1,1 ; 6,8$ & $59,9 \pm 1,5 ; 8,9$ & $22,1 \pm 0,4 ; 2,7$ \\
$\begin{array}{l}15 \text { years } \\
\text { old } \\
16 \text { years }\end{array}$ & 18 & $175,3 \pm 1,6 ; 6,6$ & $64,4 \pm 1,9 ; 8,0$ & $20,9 \pm 0,4 ; 1,7$ \\
old & 23 & $178,3 \pm 1,1 ; 6,3$ & $74,3 \pm 1,63 ; 9,4$ & $23,3 \pm 0,4 ; 2,0$ \\
\hline
\end{tabular}


Table 2. Cental tables of distribution of length and body weight of hockey players from 13 years to 16 years

\begin{tabular}{|c|c|c|c|c|c|c|c|}
\hline \multirow{2}{*}{ Group } & \multicolumn{7}{|c|}{ Cental interval } \\
\hline & $3 \%$ & $10 \%$ & $25 \%$ & $50 \%$ & $75 \%$ & $90 \%$ & $97 \%$ \\
\hline \multicolumn{8}{|c|}{ Body length (cm) } \\
\hline 13 years old & 145,0 & 152,0 & 153,5 & 159,0 & 166,5 & 172,0 & 175,0 \\
\hline 14 years old & 155,0 & 161,0 & 165,0 & 170,0 & 173,5 & 177,0 & 178,0 \\
\hline 15 years old & 159,0 & 165,0 & 173,0 & 177,0 & 180,0 & 183,0 & 183,0 \\
\hline 16 years old & 166,0 & 170,0 & 173,0 & 180,0 & 182,0 & 187,0 & 188,0 \\
\hline \multicolumn{8}{|c|}{ Body mass (kg) } \\
\hline 13 years old & 34,00 & 43,00 & 47,50 & 52,50 & 56,00 & 65,00 & 66,00 \\
\hline 14 years old & 40,00 & 48,00 & 53,50 & 63,00 & 65,50 & 70,00 & 73,00 \\
\hline 15 years old & 47,00 & 48,00 & 61,00 & 67,50 & 70,00 & 72,00 & 73,00 \\
\hline 16 years old & 55,00 & 61,00 & 68,00 & 75,00 & 79,00 & 87,00 & 100,00 \\
\hline \multicolumn{8}{|l|}{ BMI (kg/m²) } \\
\hline 13 years old & 16,2 & 17,5 & 18,7 & 20,5 & 21,6 & 23,2 & 23,4 \\
\hline 14 years old & 18,7 & 19,3 & 19,9 & 22,1 & 23,2 & 25,2 & 29,2 \\
\hline 15 years old & 17,3 & 18,8 & 19,7 & 21,1 & 22,2 & 23,1 & 23,1 \\
\hline 16 years old & 19,3 & 20,6 & 22,0 & 23,5 & 24,7 & 25,4 & 28,6 \\
\hline
\end{tabular}

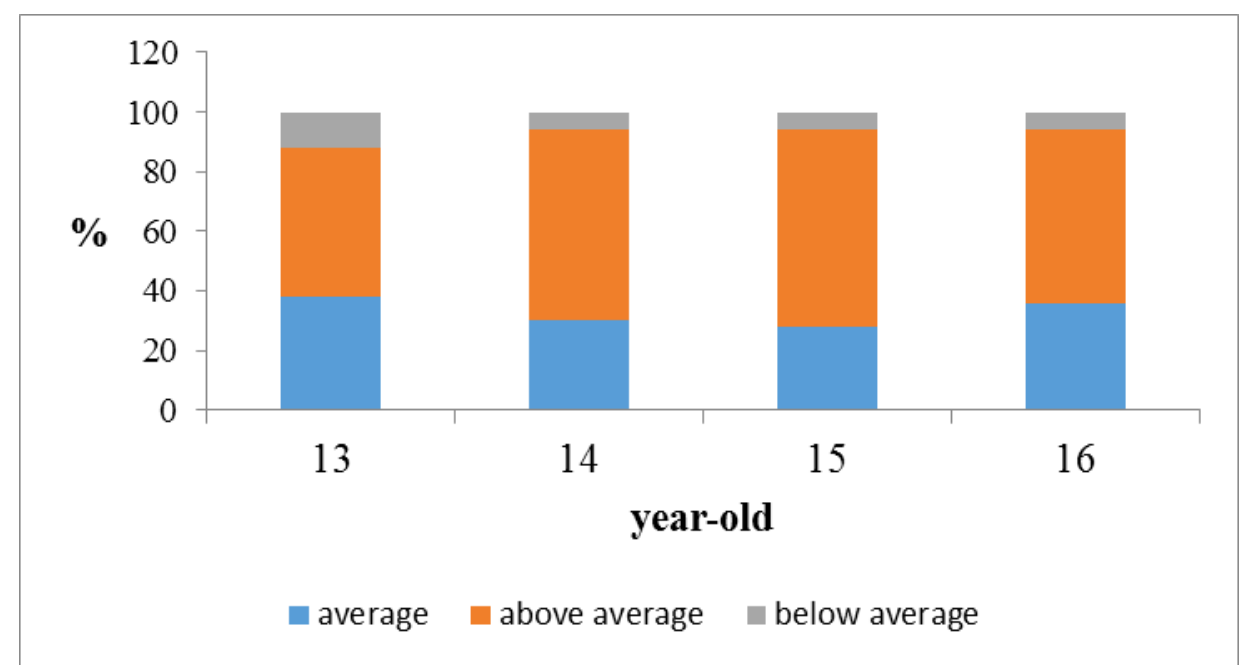

Fig. 1. In-group distribution of hockey players from 13 to 16 years old according to the body length relative to nomograms

In 13 years $37 \%$ of hockey players were characterized by BMI "above average". At 14 years the part of hockey players of this group increased to 53\% (Figure 3).

The proportion of players with average BMI values in this age group was approximately the same (50-47\%). At the age of 15 most athletes had average absolute values of BMI: $22 \%$ - "above average" and 11\% - "below average". Among hockey players aged 16 years old 61\% had absolute values more than age-sex norms. "Average" level is established in 39\% of hockey players. The relative number of hockey players with the BMI level "below the average" was established in groups of 13 years $(13 \%)$ and 15 years $(12 \%)$ old.

\section{Discussion.}

The process of sports training for children and adolescents in SCYSOR is limited by the program on ice hockey [28]. According to the literature, children are already selected in the initial training groups, among whom the majority have average length and body weight [1]. The proportion of children with "below-average" parameters is only $17 \%$ and $8 \%$ respectively. At the same time, $84 \%$ of hockey players in the initial training groups are developed harmoniously: BMI does not go beyond the average population values [1]. At the age of 13, hockey players are comparable in length and body weight with peers who do not engage in sports. There is no statistically significant difference in anthropometric parameters. However, hockey players exceed their peers in terms of 


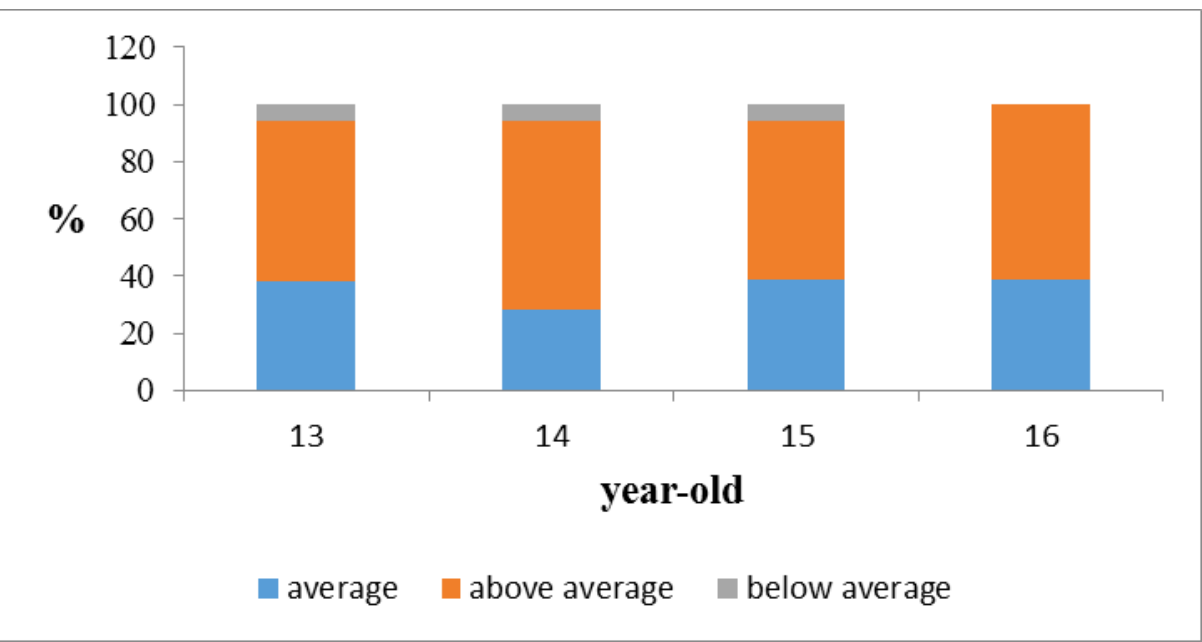

Fig. 2. Intra-group distribution of hockey players from 13 to 16 years old according to the body weight relative to nomograms

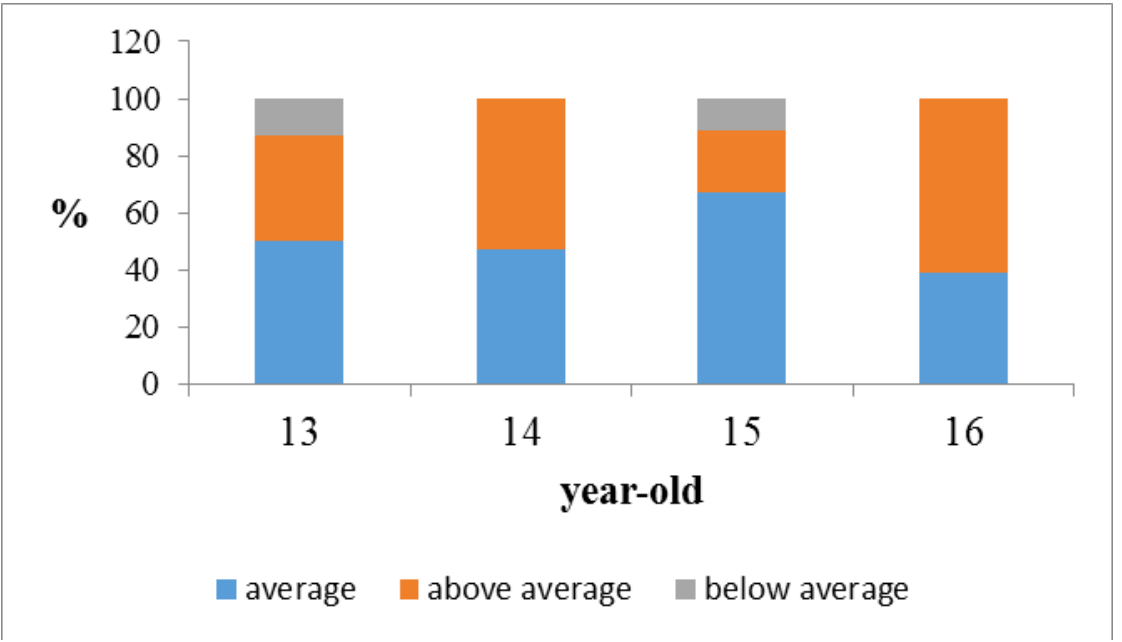

Fig. 3. Intra-group distribution of hockey players from 13 to 16 years old according to the BMI relative to nomograms

body density. This fact is confirmed by a shift in the values of the centile distribution to the right along the length and mass of the body. We were unable to compare data on hockey players from other regions of Russia: the lack of up-to-date informative data. Hockey players had large total body sizes and BMI compared to peers engaged in football in teams of professional clubs [29].

Players 14 years of age were the same length of the body with peers who do not engage in sports. At the same time, there is a distinct tendency of the shift of the centile distribution relative to the age nomograms to the right. This is especially true for hockey players with very high growth. The body weight of 14 summer hockey players was more in comparison with the teenagers, not engaged in sports. This is indicated by a shift in the values of the centile distribution to the right and an increase in BMI. BMI of 14 years old hockey players has become more approximate to the values of adult highly skilled hockey players [16-18]. Compared to peer-to-peer players [29, $30]$, hockey players of this age have large BMI values, length and body weight.

At the age of 15 at the length of the body, hockey players are similar to peers who do not engage in sports.
But hockey players are distinguished by large body weight and BMI. The centrally distributed parameters of the physical development of players of this age are characterized by a shift to the right along the length of the body and an even larger shift in body weight. In this case, tall hockey players and (or) having a large body weight (97\% percentile or less) do not differ from their peers who do not engage in sports. According to the BMI the cental distribution of 15 years old hockey players differs only in the expansion of the range of average values. $\mathrm{BMI}$ in the zone of high and very high values becomes less compared with peers who do not engage in sports. At the age of 15, hockey players from Canada and the United States begin to be selected as professional teams [31]. Already at this age they begin to differ from the players of leading team of Russia in terms of physical development. Hockey players of Canada are more than Russian hockey players in total body size and BMI [31, 32]. This fact is due to the existence of a smaller number of hockey infrastructure facilities in Russia. Therefore, there is a significant lag behind other leading hockey countries in the relative number of children and teenagers engaged in ice hockey. This reduces the competition in 
children's and youth sports. Indirect influence of the level of hockey development and the level of competition on the parameters of the physical development of players is confirmed by the fact of a shorter body length for hockey players of the Republic of Belarus [33]. At the age of 15, the total body size of hockey players with a puck is similar in their average values to football players [29, 30]. This is determined by the criteria for sports selection at the stage of sports improvement when moving to professional football.

At the age of 16, hockey players differ in their body weight and BMI from peers who do not engage in sports. For comparison, we used the data of the leading hockey teams of the zone "Ural-Western Siberia" [1]. Hockey players of the South Ural region are distinguished by a smaller span of centile intervals (" $25 \%-75 \%$ " percentile). They have an extension to the right of the interval "less than $25 \%$ percentile" along the length of the body. The physical development of elite hockey players in the South Ural region is characterized by a higher BMI score. 16 years old hockey players are characterized by large total body sizes compared to football players. This confirms the specificity of the body weight and BMI for ice hockey. This is due to the forceful style of fighting on hockey grounds and a higher probability of injuries in a collision. Therefore, when selecting young people, coaches pay more attention to the parameters of body weight and BMI of hockey players. At the youthful age (17-21 years) hockey players also have a large mass in comparison with football players [29] and representatives of cyclic sports [34].

The BMI value is the selection criterion. This confirms the existence of a high degree of interrelation between the BMI and the maximum speed of movement, the level of speed-strength qualities [29, 35]. Significant BMI values may increase the risk of injuries among hockey players [18].

Hockey as a sport belongs to acyclic situational sports. The success of a competitive struggle depends on a very large number of factors. This leads to an expansion of the range and variability of parameters in the model characteristics of the hockey player. From the age of 13 the hockey team becomes more variable in length and body weight. Appears a small group of hockey players with a body length "below average". In the future, the intragroup distribution of players along the length of the body becomes more stable: a group of athletes with the "below average" level decreases to a minimum and remains up to 16 years. A group of players with a body weight of "below average" is very small. This group stands out in the teams of hockey players only to 15 years of age. The largest representation in the hockey team has a group with a body weight of "above average" (with a maximum of 14 and 16 years). Relative heterogeneity in body weight is due to the discrepancy in the rates of biological maturation in the pubertal period of development of hockey players $[5,36]$. Hockey players with a shorter body length and body weight undergo sport selection due to the high level of development of other qualities of importance for hockey [37]. In 11-12 and 13 years in the hockey team appears a group of hockey players with BMI "below average". This group is most numerous at the age of 13 . This is due to intra-group differences in the timing of the onset of puberty. At the age of 14 and 15, the intragroup distribution of hockey players according to BMI varies considerably in the ratio between the individual groups. This is due to differences in the rates of biological development of players of different roles. At the age of 16 , the increase in the absolute body weight of hockey players contributes to the disappearance of a group of players with BMI below the average population values. A significant decrease in intra-group variability is due to higher requirements to the parameters of physical development. This is very important to take into account in sports selection in youth hockey.

\section{Conclusions.}

The physical development of elite hockey players of 13-16 years old is characterized by an average body length with a tendency to shift to "above average" values. The proportion of hockey players with mean body lengths below the mid-population is very small.

Elite hockey players at 14 and 16 years old have different body weight and BMI compared to peers who do not go in for sports. The proportion of hockey players with body weight values below the average population is very small. This is observed only at the age of 13 to 15 years old.

The physical development of hockey players from 13 to 16 years old is characterized by large total body size and BMI relative to representatives of other game sports.

As the age increases from the morphological criteria, the body weight and BMI have the greatest value for the success of the hockey player in the passage of the stages of sports selection.

\section{Acknowledgements.}

We express gratitude for the help in organization of research work to the head of Department on physical culture, sports and tourism management of Administration of Chelyabinsk Eugene Viktotivich Ivanov, Director of specialized school of Olympic reserve "Tractor" Vyacheslav Eugenievich Ugryumov, the Deputy Director of the specialized school of Olympic reserve "Tractor" Vladimir Aleksandrovich Molchanov, doctor of specialized school of Olympic reserve "Traktor" Olga Stepanovna Zolotareva.

\section{Financing}

The work was supported by Government of the Russian Federation (Resolution No.211 from 16.03.2013), agreement No. 02.A03.21.0011

The research was carried out within the framework of the state task of the Ministry of Education and Science of the Russian Federation (grant No. 19.9731.2017/BCH).

\section{Conflict of interest}

The authors state that there is no conflict of interest. 


\section{References}

1. Antipova OS. Morphological features of physical development of hockey players as a result of adaptation to training in training in sports schools. Vestnik Nizhnevartovskogo gosudarstvennogo universiteta, 2016; 4: 56-63. (in Russian)

2. Babikova AS, Nasybullina GM. The health status of children systematically engaged in sports. Biulleten' VostochnoSibirskogo nauchnogo centa Sibirskogo otdeleniia RAMN. 2013; 3; 91:40-3. (in Russian)

3. Lindt TA. Indicators of physical development of hockey players at the age from 11 to 21 years. Lechebnaia fizicheskaia kul'tura i sportivnaia medicina, 2016; 1: 12-17. (in Russian)

4. Kuchma VR. Hygiene of children and adolescents. Moscow: NCPD RAMS; 2013. (in Russian)

5. Shajkhelislamova MV, Sitdikov FG, Dikopol'skaia NB, Bilalova GA, Zotova FR. Condition of the adrenal cortex in young hockey players of pubertal age. Teoriia i praktika fizicheskoj kul'tury. 2016; 4:14-17. (in Russian)

6. Stepanova AV, Godina EZ, Khomiakova IA, Zadorozhnaia LV, Stepanova AV. Monitoring of growth processes in children and adolescents with tall. Vestnik Moskovskogo universiteta. Seriia XXIII Antropologiia. 2012; 4: 84-97. (in Russian)

7. Podrigalo LV, Iermakov SS, Jagiello W. Special indices of body composition as a criterion of somatic development of martial arts practitioners. Archives of Budo Science of Martial Arts and Extreme Sports. 2017;13:5-12.

8. Jagiełło M, Iermakov SS, Nowiński M. Differentiation of the somatic composition of students physical education specialising in various sports. Archives of Budo Science of Martial Arts and Extreme Sports. 2017;13:63-70.

9. Iordanskaia FA. Features of adaptation of cardiovascular system of young athletes to loads in modern hockey with a puck. Vestnik sportivnoj nauki, 2010. 3: 33-38. (in Russian)

10.Malina RM. Early sport specialization: roots, effectiveness, risks. Curr Sports Med Rep. 2010; 9(6):364-371. doi:10.1249/ JSR.0b013e3181fe3166

11.Jagiello W, Kruszewski A. Morphological diversification of competitors training Greco-Roman style of wrestling. Archives of Budo. 2009;5: 147-153.

12. Osipov AY, Kudryavtsev MD, Iermakov SS, Jagiello W. Topics of doctoral and postdoctoral dissertations devoted to judo in period 2000-2016-the overall analysis of works of Russian experts. Archives of Budo. 2017;13:1-10.

13.Osipov AY, Kudryavtsev MD, Iermakov SS, Jagiello W. Criteria for effective sports selection in judo schools - on example of sportsmanship's progress of young judo athletes in Russian Federation. Archives of Budo. 2017;13:179-186.

14.Samsonova AV, Mikhno LV. Age and physical development of hockey players participating in the Olympic Games. 2014. Uchenye zapiski universiteta im. P.F. Lesgafta, 2014;115(9):131-135. (in Russian)

15.Kutáč P, Sigmund M. A. Comparison of Somatic Variables of Elite Ice Hockey Players from the Czech ELH and Russian KHL. J Hum Kinet. 2015;45:187-195. doi:10.1515/ hukin-2015-0019

16. Montgomery DL. Physiological profile of professional hockey players - a longitudinal comparison. Appl. Physiol. Nutr.Metab; 2006;31:181-185. doi:10.1139/H06-012

17.Roczniok R, Stanula A, Maszczyk A, Mostowik A, Kowalczyk M, Fidos-Czuba O, et al. Physiological, physical and on-ice performance criteria for selection of elite ice hockey teams. Biol Sport. 2016;33(1):43-48. doi:10.5604/20831862.1180175

18.Grant JA, Bedi A, Kurz J, Bancroft R, Gagnier JJ, Miller
BS. Ability of preseason Body Compozition and Physical Fitness to Predict The Risk of Injury in Male Collegiate Hockey Players. Sports Health. 2015; 7(1): 45-51. doi:10.1177/19417388114540445

19.Kontos AP, Elbin RJ, Sufrinko A, Dakan S, Bookwalter K, Price A, et al. Incidence of Concussion in Youth Ice Hockey Players. Pediatrics. 2016; 137(2): e20151633. doi:10.1542/ peds.2015-1633

20.Linzmeier KA, LaBella CR. Concussions in Collision Youth Sports. Pediatr Neurol Briefs. 2016;30(1):3. doi:10.15844/ pedneurbriefs-30-1-2

21.Popkin ChA, Schulz BM, Park CN, Bottiglieri ThS, Lynch TS. Evaluation, management and prevention of lower extremity youth ice hockey injuries. J Sports Med. 2016;7:167-176. doi:10.2147/OAJSM.S118595

22.Pavlova NV, Antipova OS. Selection and orientation of young hockey players in the system of long-term sports training. Omsk: SibGUFK; 2016. (in Russian)

23.Uzunova AN, Zajceva ML. The main regularities of the physical development of children. Chelyabinsk: PEARC; 2015. (in Russian)

24.Kulaga Z, Litwin M, Tkaczyk M, Rózdzyńska A, Barwicka K, Grajda A, Swiader A, Gurzkowska B, Napieralska E, Pan $\mathrm{H}$. The height-, weight-, and BMI-for-age of Polish schoolaged children and adolescents relative to international and local growth references. BMC Public Health. 2010;4(10):109. doi:10.1186/1471-2458-10-109

25.Bykov EV. Influence of the level of motor activity on the functional state of healthy students and the physiological justification of recreational and correctional programs. Dokt. Diss., Mound; 2002. (in Russian)

26.Shibkova DZ, Bajguzhin PA, Semenova MV. Morphofunctional and psychophysiological features of schoolchildren's adaptation to educational activity. Chelyabinsk: South Ural State University for the Humanities and Pedagogy Publ.; 2016. (in Russian)

27.International Standards for Anthropometric Assessment. 2001. [Internet] 2017 Nov 1 [updated 2018 Jan 1; cited 2017 Nov 8]. Available from: http://www.ceap.br/material/ MAT17032011184632.pdf

28.Savin VP. Hockey: program of sports training for children and youth sports schools, specialized children's and youth sports schools of the Olympic reserve. Moscow; 2009. (in Russian)

29.Sinovas CM, Pérez-López A, Álvarez Valverde I, Cerezal $\mathrm{AB}$, Ramos-Campo DJ, Rubio-Arias JA, et al. Influence of body composition on vertical jump performance according with the age and the plaing position in football players. Nutr Hosp. 2015; 32(1):299-307. doi:10.3305/nh.2015.32.1.8876

30.Kniazev MM. Somatotypes of players on the playing role at the stage of early specialization. Sovremennye problemy nauk i obrazovaniia, 2015. 5: 36-40. (in Russian)

31.Sherar LB, Baxter-Jones AD, Faulkner RA, Russel KW. Do physical maturity and birth date predict talent in male youth ice hockey players? Journal of Sports Sciences, 2007;104:702-706. doi:10.2466/PMS.104.3.702-706

32.Sherar LB, Bruner MW. Relative age and fast tracking of elite major junior ice hockey players. Perceptual and Motor Skills. 2007;25(8):879-886. doi:10.1080/02640410600908001

33.Zhidkov AV. Features of development of hockey players. The International Scientific Conference of Young Scientists "Student Science of the Moscow Region", Moscow; 2015. P. 78-79. (in Russian)

34.Filatova OV, Khokhlovkina EV, Kloc VM, Zviaginceva LA. Peculiarities of the distribution of somatotypes in groups of boys with different sports specialization. Izvestiia 
Altajskogo gosudarstvennogo universiteta, 2013;79(3): 5256. doi:10.14258/izvasu(2013)3.2-09 (in Russian)

35.Sedeaud A, Marc A, Marck A, Dor F, Schipman J, Dorsey M, et al. BMI, a performance parameter for speed improvement. PLoS One. 2014;9(2):e90183. doi:10.1371/journal. pone.0090183
36.Armstrong N, McManus AM. Elite Young Athlete. Med Sport Sci. 2011;56: 1-22. doi:10.1159/000320618.

37.Konovalov VN, Bernatavichius DA, Afanas'ev DA. Complex assessment of special physical fitness of young hockey players. Omskij nauchnyj vestnik, 2013;116(2): 199204. (in Russian)

\section{Information about the authors:}

Surina-Marysheva E.F.; http://orcid.org/0000-0001-7770-4338; surina-marysheva2015@yandex.ru; Institute of Sport, Tourism and Service; South Ural State University (National Research University); Soni Krivoy str., 60, Chelyabinsk, 454080, Russian Federation.

Erlikh V.V.; PhD in Biological Science, Professor; http://orcid.org/0000-0003-2640-0240; erlih-vadim@mail.ru; Institute of Sport, Tourism and Service; South Ural State University (National Research University); Soni Krivoy str., 60, Chelyabinsk, 454080, Russian Federation.

Korableva Y.B. (Corresponding author) ; http://orcid.org/0000-0003-2337-3531; julya-74@yandex.ru; Institute of Sport, Tourism and Service; South Ural State University (National Research University); Soni Krivoy str., 60, Chelyabinsk, 454080, Russian Federation.

Kantyukov S.A.; http://orcid.org/0000-0002-8067-4982; skantyukov@mail.ru;Department of Biological Chemistry, South Ural State Medical University; Vorovsky str., 36, Chelyabinsk, 454092, Russian Federation.

Ermolaeva E.N.; http://orcid.org/0000-0003-0309-5802; ermen33@mail.ru;_Department of Pathological Physiology, South Ural State University (National Research University); Vorovsky str., 36, Chelyabinsk, 454092, Russian Federation.

Cite this article as: Surina-Marysheva EF, Erlikh VV, Korableva YB, Kantyukov SA, Ermolaeva EN. Physical development of hockey players aged 13-16 years. Pedagogics, psychology, medical-biological problems of physical training and sports, 2018;22(2):107-113. doi:10.15561/18189172.2018.0207

The electronic version of this article is the complete one and can be found online at: http://www.sportpedagogy.org.ua/index.php/PPS/issue/archive

This is an Open Access article distributed under the terms of the Creative Commons Attribution License, which permits unrestricted use, distribution, and reproduction in any medium, provided the original work is properly cited (http://creativecommons.org/licenses/by/4.0/deed.en).

Received: 16.10 .2017

Accepted: 12.11.2017; Published: 30.04.2018 